\title{
A new polymorph of phenylselenium trichloride
}

\author{
Hannah R. Bloomfield and Jamie S. Ritch
}

Acta Cryst. (2019). C75, 1471-1474

\section{IUCr Journals CRYSTALLOGRAPHY JOURNALS ONLINE}

Copyright (C) International Union of Crystallography

Author(s) of this article may load this reprint on their own web site or institutional repository provided that this cover page is retained. Republication of this article or its storage in electronic databases other than as specified above is not permitted without prior permission in writing from the IUCr.

For further information see http://journals.iucr.org/services/authorrights.html 
STRUCTURAL

CHEMISTRY

ISSN 2053-2296

Received 31 August 2019

Accepted 20 September 2019

Edited by A. R. Kennedy, University of Strathclyde, Scotland

Keywords: selenium compound; polymorph; phenylselenium trichloride; crystal structure; chalcogen-halogen interaction.

CCDC reference: 1954913

Supporting information: this article has supporting information at journals.iucr.org/c

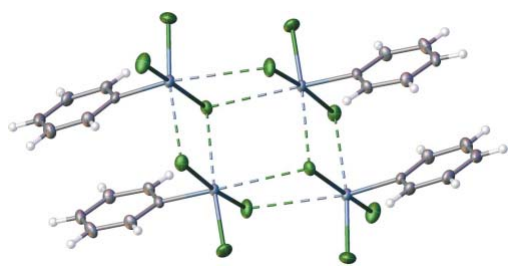

C 2019 International Union of Crystallography

\section{A new polymorph of phenylselenium trichloride}

\author{
Hannah R. Bloomfield and Jamie S. Ritch*
}

Department of Chemistry, The University of Winnipeg, 515 Portage Avenue, Winnipeg, MB, R3B 2E9, Canada *Correspondence e-mail: j.ritch@uwinnipeg.ca

A second polymorph of phenylselenium trichloride, $\mathrm{PhSeCl}_{3}$ or $\mathrm{C}_{6} \mathrm{H}_{5} \mathrm{Cl}_{3} \mathrm{Se}$, is disclosed, which is comprised of asymmetric chlorine-bridged noncovalent dimer units rather than polymeric chains. These dimers are each weakly bound to an adjacent dimer through noncovalent $\mathrm{Se}$. . Cl bonding interactions. Phenyl rings within each dimer are oriented in a syn fashion. Density functional theory (DFT) calculations reveal that the putative anti isomer is within $5 \mathrm{~kJ} \mathrm{~mol}^{-1}$ of the experimentally observed form. This structure represents the first additional polymorph discovered for an organoselenium trihalide compound.

\section{Introduction}

Organoselenium compounds are of practical interest for synthetic transformations such as allylic oxidations and epoxidations. Due to the mild conditions often required, they are capable of stereo-, regio- and chemoselective reactivity (Tiecco, 2000).

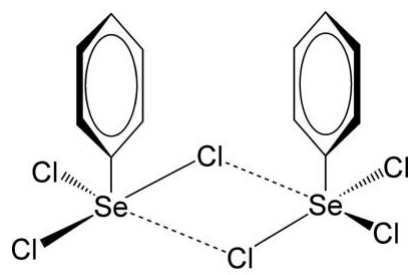

(I)

Phenylselenium trichloride is a pale-yellow hygroscopic solid (Engman, 1987). The high polarizability of selenium, paired with its high oxidizability and weaker carbon-selenium bond (compared to the sulfur analogue), makes the phenylselenium group a more versatile auxiliary group compared to the sulfur analogue (Wessjohann \& Sinks, 1998). It has found use in the large-scale synthesis of $\alpha$-phenylselenyl aldehydes (Houllemare et al., 1997) and has been reacted with alkenes to form $\beta$-chloroalkyl selenide dichloride adducts for the synthesis of polyfunctional molecules in a stereospecific manner (Garratt \& Schmid, 1974). It also been used as a successful alternative to $\mathrm{PhSeBr}_{3}$ in the synthesis of selenosulfonates, showing improved yields (Back et al., 1987).

Organoselenium halides also exhibit unique structural motifs in the solid state, due to the possibility of various combinations of chalcogen- and halogen-bonding interactions, which are subtly influenced by substituent effects and crystallization conditions. While quite a few structures have been reported for selenium(II) halogen compounds, crystallographic data for selenium(IV) compounds remain rare: 213 entries in the Cambridge Structural Database (Groom et al., 2016; Version 5.40, with updates 1 and 2) are found for the $\mathrm{C}-$ $\mathrm{Se}-X$ fragment, but only ten for the $\mathrm{C}-\mathrm{Se} X_{3}$ fragment $(X=$ $\mathrm{F}, \mathrm{Cl}, \mathrm{Br}$ and I). This dearth of structural information for 
higher-valent organoselenium halides provides an opportunity for new structural discoveries within this class of compounds.

The sole reported polymorph of $\mathrm{PhSeCl}_{3}$ (Barnes et al., 2005) exhibits a repeating polymeric motif where each $\mathrm{PhSeCl}_{3}$ molecule bridges two others via a $\mathrm{Cl}$ atom. In this article, we present a second polymorph of phenylselenium trichloride featuring a dimeric motif grown under different crystallization conditions, and examine its structural features.

\section{Experimental}

\subsection{Synthesis and crystallization}

Reactions were conducted under an inert atmosphere of argon using standard Schlenk techniques. Diethyl ether and hexanes were dried using a solvent purification system, and stored in PTFE-stoppered flasks over activated 4 A molecular sieves. $\mathrm{CDCl}_{3}$ was dried by stirring over calcium hydride, then distilled, degassed using four freeze-pump-thaw cycles and stored in a PTFE-stoppered flask over activated $4 \AA$ molecular sieves. Benzeneseleninic acid was prepared according to the reported procedure of Syper \& Młochowski (1984) and converted to benzeneseleninic anhydride by heating to $180{ }^{\circ} \mathrm{C}$ under dynamic vacuum for $3 \mathrm{~h}$. The title compound, (I), was prepared in an attempt to synthesize benzeneseleninyl chloride [i.e. $\mathrm{PhSe}(\mathrm{O}) \mathrm{Cl}$ ] via a reported procedure starting with benzeneseleninic anhydride (Rosenfeld, 1976).

For the synthesis of phenylselenium trichloride, a $100 \mathrm{ml}$ Schlenk flask was charged with phenylseleninic anhydride $(1.010 \mathrm{~g}, 2.80 \mathrm{mmol})$ and diethyl ether $(40 \mathrm{ml})$. The resulting suspension was cooled to $-78^{\circ} \mathrm{C}$ and thionyl chloride $(3.7 \mathrm{ml}$, $50.7 \mathrm{mmol}$ ) was added dropwise over a period of $2 \mathrm{~min}$. After stirring for an additional $10 \mathrm{~min}$, the mixture was allowed to warm slowly to room temperature and stirred for $2 \mathrm{~h}$, followed by gentle heating to $35^{\circ} \mathrm{C}$ for $80 \mathrm{~min}$. The volatiles were then removed under vacuum and the crude product was washed with hexanes $(3 \times 20 \mathrm{ml})$. After drying under vacuum, a palecream-coloured solid was obtained (yield: $1.405 \mathrm{~g}, 5.35 \mathrm{mmol}$, 95\%). ${ }^{1} \mathrm{H}$ NMR $\left(\mathrm{CDCl}_{3}\right): \delta 8.27-8.19(\mathrm{~m}, 2 \mathrm{H}), 7.61-7.53(\mathrm{~m}$, $3 \mathrm{H})$. Crystals suitable for X-ray diffraction were obtained from a solution of the compound in $\mathrm{CDCl}_{3}$, layered with hexanes and stored at $-20^{\circ} \mathrm{C}$.

\subsection{Refinement}

Crystal data, data collection and structure refinement details are summarized in Table 1. Carbon-bound $\mathrm{H}$ atoms were placed in calculated positions $(\mathrm{C}-\mathrm{H}=0.95 \AA)$ and refined according to a riding model, with $U_{\text {iso }}(\mathrm{H})=1.2 U_{\text {eq }}(\mathrm{C})$. No disorder or solvent molecules were noted in the difference density map.

\subsection{Computational studies}

Closed-shell density functional theory (DFT) calculations were performed using the GAMESS software package (Schmidt et al., 1993). The dispersion-corrected functional $\omega$ B97X-D (Chai \& Head-Gordon, 2008) was used, with the triple- $\zeta$ quality basis set def2-TZVP (Weigend \& Ahlrichs,
Table 1

Experimental details.

\begin{tabular}{|c|c|}
\hline \multicolumn{2}{|l|}{ Crystal data } \\
\hline Chemical formula & $\mathrm{C}_{6} \mathrm{H}_{5} \mathrm{Cl}_{3} \mathrm{Se}$ \\
\hline$M_{\mathrm{r}}$ & 262.41 \\
\hline Crystal system, space group & Triclinic, $P \overline{1}$ \\
\hline Temperature (K) & 150 \\
\hline$a, b, c(\AA)$ & $8.6245(3), 9.5342(4), 11.7229(5)$ \\
\hline$\alpha, \beta, \gamma\left({ }^{\circ}\right)$ & $78.332(2), 77.789(2), 66.341(2)$ \\
\hline$V\left(\AA^{3}\right)$ & $855.50(6)$ \\
\hline$Z$ & 4 \\
\hline Radiation type & Mo $K \alpha$ \\
\hline$\mu\left(\mathrm{mm}^{-1}\right)$ & 5.24 \\
\hline Crystal size $(\mathrm{mm})$ & $0.53 \times 0.52 \times 0.35$ \\
\hline \multicolumn{2}{|l|}{ Data collection } \\
\hline Diffractometer & Bruker APEXII CCD \\
\hline Absorption correction & $\begin{array}{l}\text { Numerical (SADABS; Bruker, } \\
\text { 2016) }\end{array}$ \\
\hline$T_{\min }, T_{\max }$ & $0.456,0.747$ \\
\hline $\begin{array}{l}\text { No. of measured, independent and } \\
\text { observed }[I>2 \sigma(I)] \text { reflections }\end{array}$ & $15455,4426,3470$ \\
\hline$R_{\text {int }}$ & 0.037 \\
\hline$(\sin \theta / \lambda)_{\max }\left(\AA^{-1}\right)$ & 0.676 \\
\hline \multicolumn{2}{|l|}{ Refinement } \\
\hline$R\left[F^{2}>2 \sigma\left(F^{2}\right)\right], w R\left(F^{2}\right), S$ & $0.029,0.051,1.05$ \\
\hline No. of reflections & 4426 \\
\hline No. of parameters & 182 \\
\hline $\mathrm{H}$-atom treatment & H-atom parameters constrained \\
\hline$\Delta \rho_{\max }, \Delta \rho_{\min }\left(\mathrm{e} \AA^{-3}\right)$ & $0.46,-0.57$ \\
\hline
\end{tabular}

2005) applied to all atoms. No symmetry restrictions were applied during geometry optimizations. The nature of all stationary points, and the Gibbs energy corrections, were obtained by analysis of the vibrational frequencies.

\section{Results and discussion}

In an attempt to prepare benzeneseleninyl chloride [i.e. $\mathrm{PhSe}(\mathrm{O}) \mathrm{Cl}$ ], we conducted the reaction of benzeneseleninic anhydride with excess thionyl chloride as described previously (Rosenfeld, 1976). In our hands, this procedure afforded an excellent yield of phenylselenium trichloride. It seems possible that in the previously described work, adventitous moisture partially hydrolyzed the $\mathrm{PhSeCl}_{3}$ product to $\mathrm{PhSe}(\mathrm{O}) \mathrm{Cl}$, which was the isolated species. This procedure therefore represents a new route to $\mathrm{PhSeCl}_{3}$, which is more commonly prepared by the chlorination of $\mathrm{Ph}_{2} \mathrm{Se}_{2}$ with $\mathrm{SO}_{2} \mathrm{Cl}_{2}$ (Engman, 1987). Other methods are known, including the reaction of benzeneseleninic acid with thionyl chloride (Stuhr-Hansen et al., 1996).

The structure of the title compound, (I), was confirmed by $\mathrm{X}$-ray studies of single crystals obtained from $\mathrm{CDCl}_{3} /$ hexanes, where a unique unit cell in the space group $P \overline{1}$ was found. The only previously characterized polymorph of $\mathrm{PhSeCl}_{3}$, also with space group $P \overline{1}$, was obtained by the slow cooling of a diethyl ether solution of the compound. The presently determined structure has a slightly larger unit-cell volume (by ca 3\%) compared to the known structure.

The unit cell contains two crystallographically independent molecules arranged in an asymmetric dimeric fashion (Fig. 1) via two Se $\cdots \mathrm{Cl}$ bridging interactions $[\mathrm{Se} \cdots \mathrm{Cl}=2.7975$ (7) and 


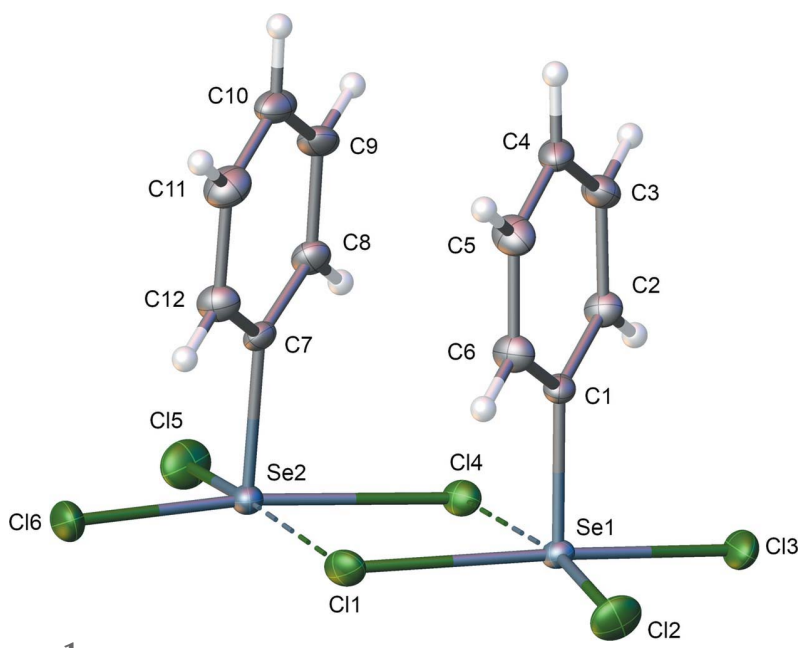

Figure 1

Displacement ellipsoid plot (non-H atoms are drawn at the $50 \%$ probability level) of the dimeric unit of $\mathrm{PhSeCl}_{3}$.

2.8070 (7) ̊]. These distances are well within the sum of the van der Waals radii of $3.65 \AA$ (Bondi, 1964). Within each monomer, the $\mathrm{Se}-\mathrm{Cl}$ bond lengths for the bridging $\mathrm{Cl}$ atoms are 2.5648 (7)-2.5900 (6) $\AA$, while for the terminal $\mathrm{Cl}$ atoms they are in the range $2.1769(7)-2.2643$ (7) $\AA$, which are in accordance with the sum of the covalent radii of $2.22 \AA$ (Cordero et al., 2008). The atoms comprising the $\mathrm{Se}_{2} \mathrm{Cl}_{6}$ unit are nearly coplanar (r.m.s. deviation of $0.060 \AA$ ), and the cis $\mathrm{Cl}-\mathrm{Se}-\mathrm{Cl}$ angles are in the range $84.06(2)-94.38(3)^{\circ}$. The two phenyl rings of the dimer adopt a syn configuration and are close to being parallel, with a mean-plane-to-mean-plane dihedral angle of $5.5(1)^{\circ}$. The centroid-to-centroid distance is 3.6987 (2) А. Given the face-to-face nature of the stacked aromatic rings, an attractive $\pi-\pi$ stacking interaction is unlikely as this orientation is normally electrostatically repulsive in nature (Martinez \& Iverson, 2012). Taking the formula as $\mathrm{C}_{6} \mathrm{H}_{5} \mathrm{SeCl}_{3}$, the unit cell features $Z=4$ (Fig. 2).

The known polymorph of $\mathrm{PhSeCl}_{3}$ (Barnes et al., 2005) exhibits a chain polymer structure through noncovalent interactions $[\mathrm{Se} \cdots \mathrm{Cl}=2.616(5)-2.726(5) \AA]$, giving each selenium centre a square-pyramidal geometry. The monomers feature similar metrical parameters to those in the present polymorph. Phenyl substituents from adjacent chains are interwoven in a slip-stacked fashion, which could possibly lead to an attractive quadrupole-quadrupole interaction between the rings (Martinez \& Iverson, 2012). Adjacent monomers feature $c a 70^{\circ}$ angles between the $\mathrm{SeCl}_{4}$ basal planes. By contrast, in the present structure, these are nearly coplanar and no polymer chains are observed. Instead, longer $\mathrm{Se} \cdot \mathrm{Cl}$ contacts in the range 3.3760 (6)-3.4099 (7) $\AA$ join two adjacent dimeric units related by a centre of symmetry, giving each selenium centre a pseudo-octahedral geometry and forming a double seco-cubane motif (Fig. 3). These $\mathrm{Se}_{4}$ clusters are weakly bound to adjacent clusters via type I chlorine...chlorine contacts of $c a 3.3 \AA$, forming chains.

Two para-halogenated analogues of $\mathrm{PhSeCl}_{3}$ have been crystallographically characterized (Barnes et al., 2012). The fluorinated molecule crystallizes in the $C 2 / c$ space group and

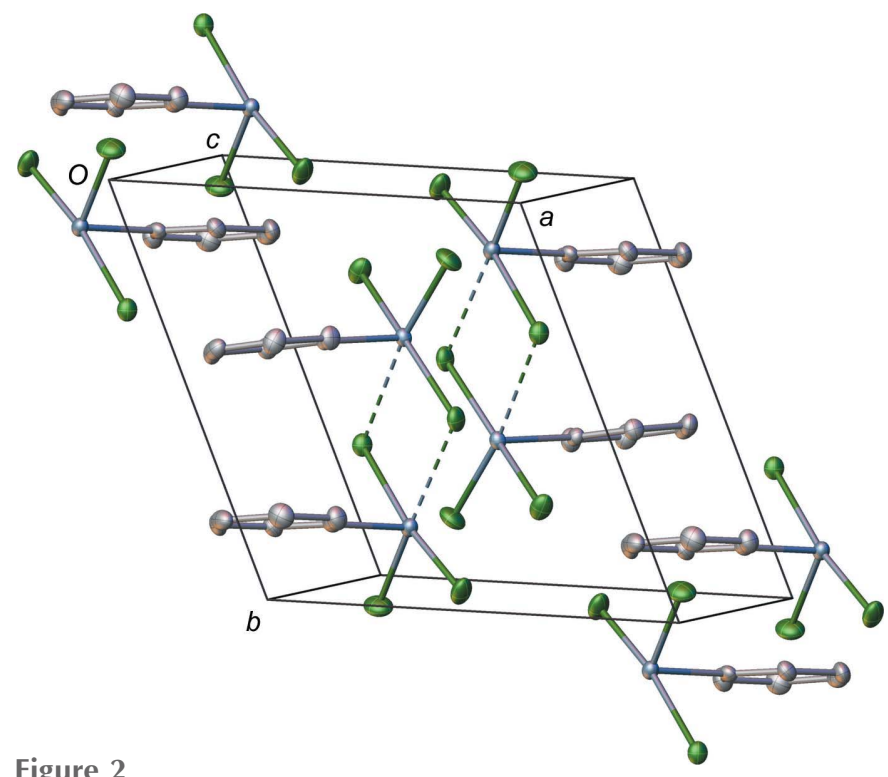

The packing diagram for $\mathrm{PhSeCl}_{3}$.

features a structural motif quite similar to the new $\mathrm{PhSeCl}_{3}$ polymorph, with two syn dimers linked together to give pseudo-octahedral selenium centres with similar bond lengths and angles. The chlorinated molecule also crystallizes in the $C 2 / c$ space group, but is a cocrystallized mixture of $s y n$ - and anti-configuration dimers, and only one of the Se atoms within the syn-conformer features an additional $\mathrm{Se} \cdot \mathrm{Cl}$ contact to another dimer. This previous study illustrates the effect aromatic ring substituents can have on the aggregation between $\operatorname{ArSe} X_{3}$ fragments. The present discovery of an additional polymorph of $\mathrm{PhSeCl}_{3}$ further illustrates that changing aggregation is possible by simply varying the crystallization conditions, e.g. solvent choice.

To gain further insight into the energetics of the $\mathrm{PhSeCl}_{3}$ system, DFT calculations were performed on the $\mathrm{PhSeCl}_{2}(\mu$ $\mathrm{Cl})_{2} \mathrm{SeCl}_{2} \mathrm{Ph}$ dimers. Several dispersion-corrected functionals (B97-D3, M06-2X, PBE0-D3 and $\omega$ B97X-D) were tested to examine how closely they reproduced the experimental geometry of the dimer (ignoring the long-range $\mathrm{Se} \cdots \mathrm{Cl}$ contacts). The M06-2X functional had convergence issues and

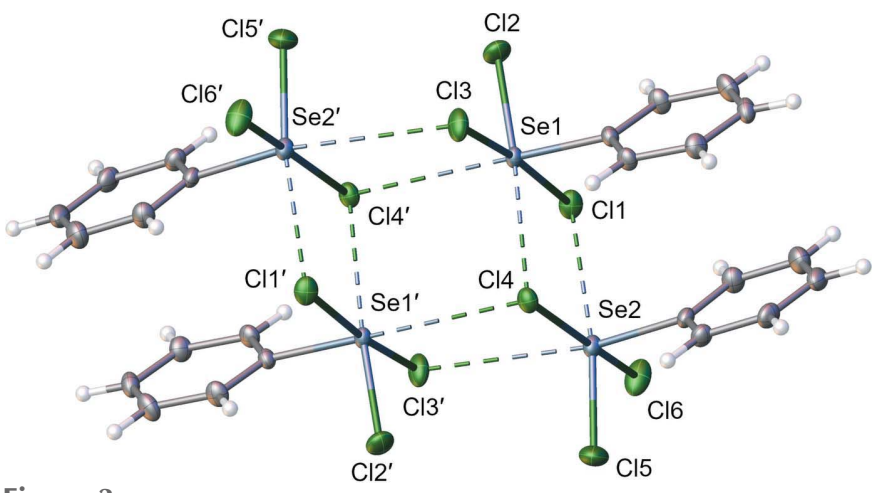

Figure 3

Secondary bonding interactions in the crystal structure of $\mathrm{PhSeCl}_{3}$. Atoms marked with a prime symbol are related to the unprimed atoms by $(-x+1,-y+1,-z+1)$. 
both functionals using Grimme's D3 dispersion correction yielded symmetrically-bridging $\mathrm{Cl}$ atoms. Only the $\omega \mathrm{B} 97 \mathrm{X}-\mathrm{D}$ functional closely reproduced the asymmetric dimer structure. Bond lengths were closely replicated, though the two bridging interactions linking each $\mathrm{PhSeCl}_{3}$ monomer were longer than experimentally observed by $\mathrm{ca} 7 \%$, and the two phenyl rings were slightly slipped from a face-to-face orientation. It is possible that attempting to model a second dimer and the corresponding long-range contacts would result in a more accurate geometry reproduction, though it was deemed too computationally expensive at this level of theory.

When the hypothetical anti isomer was modelled it also exhibited an asymmetric dimer motif, with a Gibbs energy only ca $5 \mathrm{~kJ} \mathrm{~mol}^{-1}$ higher than the syn isomer. While these computations are simplified from the solid-state structure, they illustrate the small energy differences between various conformers and highlight that other polymorphs, i.e. the anti isomer of $\mathrm{PhSeCl}_{3}$, may be experimentally accessible under the right crystallization conditions.

\section{Acknowledgements}

Dr David Herbert (Department of Chemistry, University of Manitoba) is thanked for access to a single-crystal X-ray diffractometer. Funding for this research was provided by the Natural Sciences and Engineering Research Council of Canada.

\section{References}

Back, T. G., Collins, S. \& Krishna, M. V. (1987). Can. J. Chem. 65, 3842.
Barnes, N. A., Godfrey, S. M., Halton, R. T. A. \& Pritchard, R. G. (2005). Dalton Trans. pp. 1759-1761.

Barnes, N. A., Godfrey, S. M., Ollerenshaw, R. T. A., Khan, R. Z. \& Pritchard, R. G. (2012). Dalton Trans. 41, 14583-14593.

Bondi, A. (1964). J. Phys. Chem. 68, 441-451.

Bruker (2016). $A P E X 3, S A I N T$ and $S A D A B S$. Bruker AXS Inc., Madison, Wisconsin, USA.

Chai, J.-D. \& Head-Gordon, M. (2008). Phys. Chem. Chem. Phys. 10, 6615-6620.

Cordero, B., Gómez, V., Platero-Prats, A. E., Revés, M., Echeverría, J., Cremades, E., Barragán, F. \& Alvarez, S. (2008). Dalton Trans. pp. 2832-2838.

Dolomanov, O. V., Bourhis, L. J., Gildea, R. J., Howard, J. A. K. \& Puschmann, H. (2009). J. Appl. Cryst. 42, 339-341.

Engman, L. (1987). J. Org. Chem. 52, 4086-4094.

Garratt, D. G. \& Schmid, G. H. (1974). Can. J. Chem. 52, 3599-3606.

Groom, C. R., Bruno, I. J., Lightfoot, M. P. \& Ward, S. C. (2016). Acta Cryst. B72, 171-179.

Houllemare, D., Ponthieux, S., Outurquin, F. \& Paulmier, C. (1997). Synthesis, 1997, 101-106.

Martinez, C. R. \& Iverson, B. L. (2012). Chem. Sci. 3, 2191-2201.

Rosenfeld, M. N. (1976). PhD thesis, Imperial College London, UK. Schmidt, M. W., Baldridge, K. K., Boatz, J. A., Elbert, S. T., Gordon, M. S., Jensen, J. H., Koseki, S., Matsunaga, N., Nguyen, K. A., Su, S., Windus, T. L., Dupuis, M. \& Montgomery, J. A. (1993). J. Comput. Chem. 14, 1347-1363.

Sheldrick, G. M. (2015a). Acta Cryst. A71, 3-8.

Sheldrick, G. M. (2015b). Acta Cryst. C71, 3-8.

Stuhr-Hansen, N., Henriksen, L. \& Kodra, J. T. (1996). Synth. Commun. 26, 3345-3350.

Syper, L. \& Młochowski, J. (1984). Synthesis, 1984, 747-752.

Tiecco, M. (2000). Organoselenium Chemistry. Topics in Current Chemistry, Vol. 208, edited by T. Wirth, pp. 7-54. Berlin, Heidelberg: Springer.

Weigend, F. \& Ahlrichs, R. (2005). Phys. Chem. Chem. Phys. 7, $3297-$ 3305 .

Wessjohann, L. \& Sinks, U. (1998). J. Prakt. Chem. 340, 189-203. 


\section{supporting information}

Acta Cryst. (2019). C75, 1471-1474 [https://doi.org/10.1107/S2053229619013019]

\section{A new polymorph of phenylselenium trichloride}

\section{Hannah R. Bloomfield and Jamie S. Ritch}

Computing details

Data collection: APEX3 (Bruker, 2016; cell refinement: SAINT (Bruker, 2016); data reduction: SAINT (Bruker, 2016; program(s) used to solve structure: SHELXT (Sheldrick, 2015a); program(s) used to refine structure: SHELXL (Sheldrick, 2015b); molecular graphics: OLEX2 (Dolomanov et al., 2009); software used to prepare material for publication: OLEX2 (Dolomanov et al., 2009).

Phenylselenium trichloride

Crystal data

$\mathrm{C}_{6} \mathrm{H}_{5} \mathrm{Cl}_{3} \mathrm{Se}$

$M_{r}=262.41$

Triclinic, $P \overline{1}$

$a=8.6245(3) \AA$

$b=9.5342(4) \AA$

$c=11.7229(5) \AA$

$\alpha=78.332(2)^{\circ}$

$\beta=77.789(2)^{\circ}$

$\gamma=66.341(2)^{\circ}$

$V=855.50(6) \AA^{3}$

Data collection

Bruker APEXII CCD

diffractometer

$\varphi$ and $\omega$ scans

Absorption correction: numerical

(SADABS; Bruker, 2016)

$T_{\min }=0.456, T_{\max }=0.747$

15455 measured reflections

\section{Refinement}

Refinement on $F^{2}$

Least-squares matrix: full

$R\left[F^{2}>2 \sigma\left(F^{2}\right)\right]=0.029$

$w R\left(F^{2}\right)=0.051$

$S=1.05$

4426 reflections

182 parameters

0 restraints

Primary atom site location: dual

Hydrogen site location: inferred from neighbouring sites
$Z=4$

$F(000)=504$

$D_{\mathrm{x}}=2.037 \mathrm{Mg} \mathrm{m}^{-3}$

Mo $K \alpha$ radiation, $\lambda=0.71073 \AA$

Cell parameters from 8248 reflections

$\theta=2.6-32.6^{\circ}$

$\mu=5.24 \mathrm{~mm}^{-1}$

$T=150 \mathrm{~K}$

Prism, clear colourless

$0.53 \times 0.52 \times 0.35 \mathrm{~mm}$

4426 independent reflections

3470 reflections with $I>2 \sigma(I)$

$R_{\text {int }}=0.037$

$\theta_{\max }=28.7^{\circ}, \theta_{\min }=2.6^{\circ}$

$h=-11 \rightarrow 11$

$k=-12 \rightarrow 12$

$l=-15 \rightarrow 15$

H-atom parameters constrained

$w=1 /\left[\sigma^{2}\left(F_{\mathrm{o}}^{2}\right)+(0.0095 P)^{2}+0.5686 P\right]$

where $P=\left(F_{\mathrm{o}}^{2}+2 F_{\mathrm{c}}^{2}\right) / 3$

$(\Delta / \sigma)_{\max }=0.001$

$\Delta \rho_{\max }=0.46 \mathrm{e} \AA^{-3}$

$\Delta \rho_{\min }=-0.57$ e $\AA^{-3}$

Extinction correction: SHELXL2018

(Sheldrick, 2015b),

$\mathrm{Fc}^{*}=\mathrm{kFc}\left[1+0.001 \mathrm{xFc}^{2} \lambda^{3} / \sin (2 \theta)\right]^{-1 / 4}$

Extinction coefficient: 0.0114 (3) 


\section{Special details}

Geometry. All esds (except the esd in the dihedral angle between two 1.s. planes) are estimated using the full covariance matrix. The cell esds are taken into account individually in the estimation of esds in distances, angles and torsion angles; correlations between esds in cell parameters are only used when they are defined by crystal symmetry. An approximate (isotropic) treatment of cell esds is used for estimating esds involving l.s. planes.

Fractional atomic coordinates and isotropic or equivalent isotropic displacement parameters $\left(\AA^{2}\right)$

\begin{tabular}{|c|c|c|c|c|}
\hline & $x$ & $y$ & $z$ & $U_{\text {iso }} * / U_{\text {eq }}$ \\
\hline $\mathrm{Se} 1$ & $0.46873(3)$ & $0.37174(3)$ & $0.37701(2)$ & $0.01526(7)$ \\
\hline $\mathrm{Se} 2$ & $0.33135(3)$ & $0.82730(3)$ & $0.29123(2)$ & $0.01719(7)$ \\
\hline $\mathrm{Cl} 4$ & $0.23956(8)$ & $0.64558(7)$ & $0.46326(5)$ & $0.02005(13)$ \\
\hline $\mathrm{Cl1}$ & $0.57258(8)$ & $0.55087(8)$ & $0.21325(5)$ & $0.02304(14)$ \\
\hline $\mathrm{Cl} 3$ & $0.37555(9)$ & $0.22740(8)$ & $0.53285(6)$ & $0.02807(16)$ \\
\hline $\mathrm{Cl} 2$ & $0.67527(8)$ & $0.17097(8)$ & $0.30719(6)$ & $0.02984(16)$ \\
\hline $\mathrm{Cl} 5$ & $0.15514(9)$ & $1.02879(8)$ & $0.37443(6)$ & $0.03339(17)$ \\
\hline $\mathrm{Cl} 6$ & $0.44520(9)$ & $0.96373(8)$ & $0.14372(6)$ & $0.03359(17)$ \\
\hline $\mathrm{C} 1$ & 0.3008 & $0.3840(3)$ & $0.2832(2)$ & $0.0155(5)$ \\
\hline $\mathrm{C} 7$ & $0.1696(3)$ & $0.8222(3)$ & $0.1993(2)$ & $0.0170(5)$ \\
\hline $\mathrm{C} 8$ & $0.0049(3)$ & $0.8412(3)$ & $0.2539(2)$ & $0.0199(5)$ \\
\hline $\mathrm{H} 8$ & -0.029076 & 0.855370 & 0.334641 & $0.024 *$ \\
\hline $\mathrm{C} 2$ & $0.1329(3)$ & $0.4140(3)$ & $0.3366(2)$ & $0.0185(5)$ \\
\hline $\mathrm{H} 2$ & 0.100984 & 0.424952 & 0.417965 & $0.022 *$ \\
\hline C6 & $0.3511(3)$ & 0.3669 & $0.1649(2)$ & $0.0213(5)$ \\
\hline H6 & 0.466331 & 0.347356 & 0.129613 & $0.026^{*}$ \\
\hline C9 & -0.1095 & $0.8390(3)$ & $0.1870(2)$ & $0.0235(6)$ \\
\hline H9 & -0.223387 & 0.852156 & 0.222208 & $0.028^{*}$ \\
\hline $\mathrm{C} 4$ & $0.0613(3)$ & $0.4096(3)$ & $0.1506(2)$ & $0.0218(6)$ \\
\hline $\mathrm{H} 4$ & -0.021439 & 0.418381 & 0.104667 & $0.026^{*}$ \\
\hline $\mathrm{C} 3$ & 0.0130 & $0.4276(3)$ & $0.2690(2)$ & $0.0215(6)$ \\
\hline H3 & -0.102844 & 0.449365 & 0.303758 & $0.026^{*}$ \\
\hline C12 & $0.2236(3)$ & $0.7984(3)$ & $0.0828(2)$ & $0.0229(6)$ \\
\hline H12 & 0.337873 & 0.784085 & 0.047616 & $0.027^{*}$ \\
\hline $\mathrm{C} 10$ & $-0.0587(3)$ & 0.8180 & $0.0700(2)$ & $0.0253(6)$ \\
\hline H10 & -0.138341 & 0.818728 & 0.024752 & $0.030^{*}$ \\
\hline $\mathrm{C} 5$ & 0.2290 & $0.3791(3)$ & $0.0991(2)$ & $0.0248(6)$ \\
\hline H5 & 0.261162 & 0.366247 & 0.018056 & $0.030^{*}$ \\
\hline C11 & 0.1075 (4) & 0.7958 (3) & $0.0183(2)$ & $0.0281(6)$ \\
\hline H11 & 0.142480 & 0.778644 & -0.061869 & $0.034 *$ \\
\hline
\end{tabular}

Atomic displacement parameters $\left(\AA^{2}\right)$

\begin{tabular}{lllllll}
\hline & $U^{11}$ & $U^{22}$ & $U^{\beta 3}$ & $U^{12}$ & $U^{13}$ & $U^{23}$ \\
\hline Se1 & $0.01433(13)$ & $0.01787(13)$ & $0.01336(13)$ & $-0.00551(10)$ & $-0.00342(10)$ & $-0.00121(10)$ \\
Se2 & $0.01727(13)$ & $0.01849(14)$ & $0.01750(14)$ & $-0.00836(11)$ & $-0.00562(10)$ & $0.00074(10)$ \\
Cl4 & $0.0202(3)$ & $0.0267(3)$ & $0.0139(3)$ & $-0.0100(3)$ & $-0.0013(2)$ & $-0.0028(2)$ \\
C11 & $0.0160(3)$ & $0.0320(4)$ & $0.0201(3)$ & $-0.0105(3)$ & $0.0004(2)$ & $-0.0012(3)$ \\
C13 & $0.0340(4)$ & $0.0354(4)$ & $0.0197(3)$ & $-0.0209(3)$ & $-0.0104(3)$ & $0.0092(3)$
\end{tabular}




$\begin{array}{lllllll}\text { C12 } & 0.0234(3) & 0.0235(3) & 0.0337(4) & 0.0028(3) & -0.0049(3) & -0.0083(3) \\ \text { C15 } & 0.0405(4) & 0.0216(3) & 0.0387(4) & -0.0062(3) & -0.0105(3) & -0.0118(3) \\ \text { C16 } & 0.0313(4) & 0.0375(4) & 0.0365(4) & -0.0235(3) & -0.0116(3) & 0.0146(3) \\ \text { C1 } & 0.0184(12) & 0.0160(12) & 0.0148(12) & -0.0078(10) & -0.0057(10) & -0.0016(10) \\ \text { C7 } & 0.0180(12) & 0.0139(12) & 0.0189(13) & -0.0043(10) & -0.0083(10) & 0.0002(10) \\ \text { C8 } & 0.0166(12) & 0.0199(13) & 0.0199(13) & -0.0030(10) & -0.0034(10) & -0.0028(11) \\ \text { C2 } & 0.0199(13) & 0.0221(13) & 0.0132(12) & -0.0075(11) & -0.0009(10) & -0.0041(10) \\ \text { C6 } & 0.0192(13) & 0.0285(14) & 0.0160(13) & -0.0094(11) & 0.0012(10) & -0.0056(11) \\ \text { C9 } & 0.0156(13) & 0.0227(14) & 0.0313(15) & -0.0049(11) & -0.0084(11) & -0.0011(12) \\ \text { C4 } & 0.0279(15) & 0.0236(14) & 0.0198(13) & -0.0138(12) & -0.0111(11) & 0.0012(11) \\ \text { C3 } & 0.0182(13) & 0.0258(14) & 0.0223(14) & -0.0105(11) & -0.0036(11) & -0.0018(11) \\ \text { C12 } & 0.0192(13) & 0.0277(14) & 0.0203(13) & -0.0070(11) & -0.0022(11) & -0.0046(11) \\ \text { C10 } & 0.0280(14) & 0.0209(14) & 0.0310(15) & -0.0082(12) & -0.0154(12) & -0.0026(12) \\ \text { C5 } & 0.0301(15) & 0.0333(16) & 0.0150(13) & -0.0154(13) & -0.0019(11) & -0.0062(11) \\ \text { C11 } & 0.0339(16) & 0.0312(16) & 0.0195(14) & -0.0100(13) & -0.0074(12) & -0.0052(12) \\ & & & & & & \end{array}$

Geometric parameters $\left(\AA,{ }^{\circ}\right)$

\begin{tabular}{|c|c|c|c|}
\hline $\mathrm{Se} 1-\mathrm{Cl}^{\mathrm{i}}$ & $3.3760(6)$ & $\mathrm{C} 8-\mathrm{C} 9$ & $1.393(3)$ \\
\hline $\mathrm{Se} 1-\mathrm{Cl} 4$ & $2.7975(7)$ & $\mathrm{C} 2-\mathrm{H} 2$ & 0.9500 \\
\hline $\mathrm{Se} 1-\mathrm{Cl} 1$ & $2.5648(7)$ & $\mathrm{C} 2-\mathrm{C} 3$ & $1.382(3)$ \\
\hline $\mathrm{Se} 1-\mathrm{Cl} 3$ & $2.2643(7)$ & C6- 6 & 0.9500 \\
\hline $\mathrm{Se} 1-\mathrm{Cl} 2$ & $2.1881(7)$ & $\mathrm{C} 6-\mathrm{C} 5$ & $1.388(3)$ \\
\hline $\mathrm{Se} 1-\mathrm{C} 1$ & $1.951(2)$ & $\mathrm{C} 9-\mathrm{H} 9$ & 0.9500 \\
\hline $\mathrm{Se} 2-\mathrm{Cl} 4$ & $2.5900(6)$ & $\mathrm{C} 9-\mathrm{C} 10$ & $1.378(4)$ \\
\hline $\mathrm{Se} 2-\mathrm{Cl} 1$ & $2.8070(7)$ & $\mathrm{C} 4-\mathrm{H} 4$ & 0.9500 \\
\hline $\mathrm{Se} 2-\mathrm{Cl}^{\mathrm{i}}$ & $3.4099(7)$ & $\mathrm{C} 4-\mathrm{C} 3$ & $1.388(3)$ \\
\hline $\mathrm{Se} 2-\mathrm{Cl} 5$ & $2.1769(7)$ & $\mathrm{C} 4-\mathrm{C} 5$ & $1.380(4)$ \\
\hline $\mathrm{Se} 2-\mathrm{Cl} 6$ & $2.2458(7)$ & $\mathrm{C} 3-\mathrm{H} 3$ & 0.9500 \\
\hline $\mathrm{Se} 2-\mathrm{C} 7$ & $1.955(2)$ & $\mathrm{C} 12-\mathrm{H} 12$ & 0.9500 \\
\hline $\mathrm{C} 1-\mathrm{C} 2$ & $1.389(3)$ & $\mathrm{C} 12-\mathrm{C} 11$ & $1.387(3)$ \\
\hline $\mathrm{C} 1-\mathrm{C} 6$ & $1.385(3)$ & $\mathrm{C} 10-\mathrm{H} 10$ & 0.9500 \\
\hline $\mathrm{C} 7-\mathrm{C} 8$ & $1.384(3)$ & $\mathrm{C} 10-\mathrm{C} 11$ & $1.381(4)$ \\
\hline $\mathrm{C} 7-\mathrm{C} 12$ & $1.380(3)$ & $\mathrm{C} 5-\mathrm{H} 5$ & 0.9500 \\
\hline $\mathrm{C} 8-\mathrm{H} 8$ & 0.9500 & C11-H11 & 0.9500 \\
\hline $\mathrm{Cl} 4-\mathrm{Se} 1-\mathrm{Cl} 4^{\mathrm{i}}$ & $90.204(17)$ & $\mathrm{C} 6-\mathrm{C} 1-\mathrm{C} 2$ & $121.9(2)$ \\
\hline $\mathrm{Cl1}-\mathrm{Se} 1-\mathrm{Cl} 4$ & $84.71(2)$ & $\mathrm{C} 8-\mathrm{C} 7-\mathrm{Se} 2$ & $118.66(18)$ \\
\hline $\mathrm{Cl} 1-\mathrm{Se} 1-\mathrm{Cl} 4^{\mathrm{i}}$ & $89.433(18)$ & $\mathrm{C} 12-\mathrm{C} 7-\mathrm{Se} 2$ & $119.06(18)$ \\
\hline $\mathrm{Cl} 3-\mathrm{Se} 1-\mathrm{Cl} 4^{\mathrm{i}}$ & $87.29(2)$ & $\mathrm{C} 12-\mathrm{C} 7-\mathrm{C} 8$ & $122.3(2)$ \\
\hline $\mathrm{Cl} 3-\mathrm{Se} 1-\mathrm{Cl} 4$ & $91.45(2)$ & $\mathrm{C} 7-\mathrm{C} 8-\mathrm{H} 8$ & 121.0 \\
\hline $\mathrm{Cl} 3-\mathrm{Se} 1-\mathrm{Cl} 1$ & $174.95(2)$ & $\mathrm{C} 7-\mathrm{C} 8-\mathrm{C} 9$ & $118.0(2)$ \\
\hline $\mathrm{C} 12-\mathrm{Se} 1-\mathrm{Cl} 4^{\mathrm{i}}$ & $83.89(2)$ & $\mathrm{C} 9-\mathrm{C} 8-\mathrm{H} 8$ & 121.0 \\
\hline $\mathrm{Cl} 2-\mathrm{Se} 1-\mathrm{Cl} 4$ & $172.03(2)$ & $\mathrm{C} 1-\mathrm{C} 2-\mathrm{H} 2$ & 120.7 \\
\hline $\mathrm{Cl} 2-\mathrm{Se} 1-\mathrm{Cl} 1$ & $89.87(3)$ & $\mathrm{C} 3-\mathrm{C} 2-\mathrm{C} 1$ & $118.7(2)$ \\
\hline $\mathrm{Cl} 2-\mathrm{Se} 1-\mathrm{Cl} 3$ & $93.60(3)$ & $\mathrm{C} 3-\mathrm{C} 2-\mathrm{H} 2$ & 120.7 \\
\hline $\mathrm{C} 1-\mathrm{Se} 1-\mathrm{Cl} 4$ & $89.59(7)$ & $\mathrm{C} 1-\mathrm{C} 6-\mathrm{H} 6$ & 120.8 \\
\hline $\mathrm{C} 1-\mathrm{Se} 1-\mathrm{Cl} 4^{\mathrm{i}}$ & $179.21(7)$ & $\mathrm{C} 1-\mathrm{C} 6-\mathrm{C} 5$ & $118.4(2)$ \\
\hline
\end{tabular}




\begin{tabular}{|c|c|c|c|}
\hline $\mathrm{C} 1-\mathrm{Se} 1-\mathrm{Cl}$ & $89.78(7)$ & $\mathrm{C} 5-\mathrm{C} 6-\mathrm{H} 6$ & 120.8 \\
\hline $\mathrm{C} 1-\mathrm{Se} 1-\mathrm{Cl} 3$ & $93.48(7)$ & $\mathrm{C} 8-\mathrm{C} 9-\mathrm{H} 9$ & 119.7 \\
\hline $\mathrm{C} 1-\mathrm{Se} 1-\mathrm{Cl} 2$ & $96.25(7)$ & $\mathrm{C} 10-\mathrm{C} 9-\mathrm{C} 8$ & $120.5(2)$ \\
\hline $\mathrm{Cl} 4-\mathrm{Se} 2-\mathrm{Cl} 1$ & $84.06(2)$ & $\mathrm{C} 10-\mathrm{C} 9-\mathrm{H} 9$ & 119.7 \\
\hline $\mathrm{Cl} 4-\mathrm{Se} 2-\mathrm{Cl}^{\mathrm{i}}$ & $81.751(18)$ & $\mathrm{C} 3-\mathrm{C} 4-\mathrm{H} 4$ & 119.8 \\
\hline $\mathrm{Cl} 1-\mathrm{Se} 2-\mathrm{Cl}^{\mathrm{i}}$ & $83.668(19)$ & $\mathrm{C} 5-\mathrm{C} 4-\mathrm{H} 4$ & 119.8 \\
\hline $\mathrm{Cl} 5-\mathrm{Se} 2-\mathrm{Cl} 4$ & $90.83(3)$ & $\mathrm{C} 5-\mathrm{C} 4-\mathrm{C} 3$ & $120.3(2)$ \\
\hline $\mathrm{Cl} 5-\mathrm{Se} 2-\mathrm{Cl} 1$ & $172.41(3)$ & $\mathrm{C} 2-\mathrm{C} 3-\mathrm{C} 4$ & $120.2(2)$ \\
\hline $\mathrm{Cl} 5-\mathrm{Se} 2-\mathrm{Cl}^{3}{ }^{\mathrm{i}}$ & $90.06(2)$ & $\mathrm{C} 2-\mathrm{C} 3-\mathrm{H} 3$ & 119.9 \\
\hline $\mathrm{Cl} 5-\mathrm{Se} 2-\mathrm{Cl} 6$ & $94.38(3)$ & $\mathrm{C} 4-\mathrm{C} 3-\mathrm{H} 3$ & 119.9 \\
\hline $\mathrm{Cl} 6-\mathrm{Se} 2-\mathrm{Cl} 4$ & $172.72(3)$ & $\mathrm{C} 7-\mathrm{C} 12-\mathrm{H} 12$ & 120.7 \\
\hline $\mathrm{Cl} 6-\mathrm{Se} 2-\mathrm{Cl} 1$ & $90.24(3)$ & $\mathrm{C} 7-\mathrm{C} 12-\mathrm{C} 11$ & $118.6(2)$ \\
\hline $\mathrm{Cl} 6-\mathrm{Se} 2-\mathrm{Cl}^{2}{ }^{\mathrm{i}}$ & $93.14(2)$ & $\mathrm{C} 11-\mathrm{C} 12-\mathrm{H} 12$ & 120.7 \\
\hline $\mathrm{C} 7-\mathrm{Se} 2-\mathrm{Cl} 4$ & $90.64(7)$ & $\mathrm{C} 9-\mathrm{C} 10-\mathrm{H} 10$ & 119.8 \\
\hline $\mathrm{C} 7-\mathrm{Se} 2-\mathrm{Cl} 1$ & $89.74(7)$ & $\mathrm{C} 9-\mathrm{C} 10-\mathrm{C} 11$ & $120.3(2)$ \\
\hline $\mathrm{C} 7-\mathrm{Se} 2-\mathrm{Cl}^{\mathrm{i}}$ & $170.39(7)$ & $\mathrm{C} 11-\mathrm{C} 10-\mathrm{H} 10$ & 119.8 \\
\hline $\mathrm{C} 7-\mathrm{Se} 2-\mathrm{Cl} 5$ & $95.94(7)$ & $\mathrm{C} 6-\mathrm{C} 5-\mathrm{H} 5$ & 119.8 \\
\hline $\mathrm{C} 7-\mathrm{Se} 2-\mathrm{Cl} 6$ & $93.87(7)$ & $\mathrm{C} 4-\mathrm{C} 5-\mathrm{C} 6$ & $120.5(2)$ \\
\hline $\mathrm{Se} 2-\mathrm{Cl} 4-\mathrm{Se} 1$ & $95.36(2)$ & $\mathrm{C} 4-\mathrm{C} 5-\mathrm{H} 5$ & 119.8 \\
\hline $\mathrm{Se} 1-\mathrm{Cl} 1-\mathrm{Se} 2$ & $95.70(2)$ & $\mathrm{C} 12-\mathrm{C} 11-\mathrm{H} 11$ & 119.9 \\
\hline $\mathrm{C} 2-\mathrm{C} 1-\mathrm{Se} 1$ & $118.78(17)$ & $\mathrm{C} 10-\mathrm{C} 11-\mathrm{C} 12$ & $120.3(2)$ \\
\hline $\mathrm{C} 6-\mathrm{C} 1-\mathrm{Se} 1$ & $119.29(18)$ & $\mathrm{C} 10-\mathrm{C} 11-\mathrm{H} 11$ & 119.9 \\
\hline
\end{tabular}

Symmetry code: (i) $-x+1,-y+1,-z+1$. 